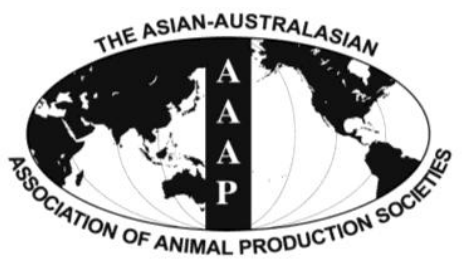

Asian-Aust. J. Anim. Sci.

Vol. 26, No. 2 : 189-194 February 2013

http://dx.doi.org/10.5713/ajas.2012.12466

www.ajas.info

pISSN 1011-2367 elSSN 1976-5517

\title{
Effects of Lactation Stage and Individual Performance on Milk cis-9, trans-11 Conjugated Linoleic Acids Content in Dairy Cows
}

\author{
T. Wang ${ }^{\text {a }}$, J. J. Oh ${ }^{\text {a }}$, J. N. Lim, J. E. Hong, J. H. Kim, J. H. Kim ${ }^{1}$, H. S. Kang, Y. J. Choi ${ }^{2}$ and H. G. Lee* \\ College of Natural Resources and life Science, Pusan National University, Miryang, Gyeongnam 627-706, Korea
}

\begin{abstract}
The goal of this study was to evaluate the effects of lactation stage and individual performance on milk cis-9, trans-11 conjugated linoleic acid (CLA) content in dairy cows. In experiment 1, the milk cis-9, trans-11 CLA content from dairy cows in early $(0.33 \pm 0.014 \%)$, middle $(0.37 \pm 0.010 \%)$, and late stages $(0.44 \pm 0.020 \%)$ showed significant differences $(\mathrm{p}<0.05)$; and the individual contents of the major fatty acids, especially cis-9, trans-11 CLA in cows of the same lactation were also variable. In the second experiment design as a validation test, our results once again showed that the individual contents of cis-9, trans-11 CLA were various, and a difference of about 2 -fold $(0.55 \%$ vs $0.95 \%)$ was observed, although the animals were offered same diet. These data demonstrated that lactation stage and individual performance have considerable effects on milk cis-9, trans-11 CLA contents. (Key Words: cis-9, trans-11 CLA, Individual Performance, Lactation Stage)
\end{abstract}

\section{INTRODUCTION}

Conjugated linoleic acid (CLA) is a group of isomers that has beneficial health effects in humans and animals (Bauman et al., 2000). Of the various potential isomers, cis9, trans-11 CLA accounts for 82 to $97 \%$ and 57 to $85 \%$ of the total CLA content in milk and beef, respectively (Dhiman et al., 2005). This specific isomer exhibits several health benefits that are not shown by other CLA isomers (Wang and Lee, 2012) thereby leading to heightened interest in the manufacture of cis-9, trans-11 CLA-fortified products (Dhiman et al., 2005; Rodríguez-Alcalá and Fontecha, 2007). The majority of the cis-9, trans-11 CLA found in milk is synthesized in mammary glands, in a process catalysed by stearoyl-CoA desaturase 1 (SCD1), while the remaining part is derived from the rumen (Bauman et al., 2000; Griinari et al., 2000; Wang and Lee, 2012). SCD1 is one of the two identified SCD isoforms in the bovine (Paton and Ntambi, 2009). It is an enzyme that

\footnotetext{
* Corresponding Author: H. G. Lee. Tel: +82-55-350-5516, Fax: +82-55 350-5519, E-mail: hglee66@pusan.ac.kr

${ }^{1}$ Research and Technology Center, Cargill Agri Purina, Seongnam 463-808, Korea.

${ }^{2}$ Laboratory of Animal Cell Biotechnology, Department of Agricultural Biotechnology, Seoul National University, Seoul 157-921, Korea.

${ }^{\mathrm{a}} \mathrm{T}$. Wang and J. J. Oh contributed equally to this manuscript. Submitted Sept. 2, 2012; Accepted Oct. 11, 2012; Revised Oct. 18, 2012
}

predominantly exists in the endoplasmic reticulum (ER) membrane of liver, mammary gland, adipose tissue, etc. (Wang and Lee, 2012). SCD5 is another SCD isoform which is highly expressed in the brain (Lengi and Corl, 2007) and it is also expressed in the bovine mammary tissue (Jacobs, 2011).

Factors that regulate the SCD1 activity or rumen fermentation conditions can alter the milk content of cis-9, trans-11 CLA. The effects of breed, diet, feeding strategies and seasonal variations have been reported (Dhiman et al., 2005; Slots et al., 2008). However, the effects of lactation stage and individual variation among dairy cows on the cis9, trans-11 CLA content are still not well understood. Therefore, in this study, two experiments were conducted in order to evaluate the effects of lactation stage and individual performance on milk cis-9, trans-11 CLA content in dairy cows.

\section{MATERIALS AND METHODS}

\section{Cows and milk samples}

Two experiments were performed in this study. All experimental procedures were in accordance with the "Guidelines for the Care and Use of Experimental Animals of Pusan National University". Experiment 1 employed thirty-one multiparous Holstein cows fed the same total mixed ration (TMR) (Tables 1 and 2). Experiment 2 used seventeen multiparous Holstein cows $(589 \pm 29.6 \mathrm{~kg}$ of body 
Table 1. Design of experiment 1

\begin{tabular}{lccc}
\hline Item & Early stage & Middle stage & Late stage \\
\hline Number & 11 & 11 & 9 \\
Weight $(\mathrm{kg})$ & $576 \pm 20.1$ & $570 \pm 20.0$ & $573 \pm 19.5$ \\
Parity & $3.0 \pm 0.38$ & $2.8 \pm 0.50$ & $1.7 \pm 0.22$ \\
Milk yield $(\mathrm{kg})$ & $32.6 \pm 1.66$ & $30.8 \pm 1.58$ & $25.8 \pm 1.73$ \\
Dry matter intake $(\mathrm{kg})$ & $23.2 \pm 2.80$ & $21.9 \pm 2.72$ & $18.7 \pm 2.59$ \\
\hline
\end{tabular}

weight) in the middle lactation stage $(142.5 \pm 29.65 \mathrm{~d})$ and fed the same diet. The ratio of roughage to concentrates was about 0.77:1 (dry matter basis); $10 \mathrm{~kg}$ of oat hay (dry matter $91.5 \%$, crude protein $1.2 \%$, ether extract $2.3 \%$, neutral detergent fiber $58.3 \%$, acid detergent fiber $36.7 \%$, and ash $8.3 \%)$ and $13 \mathrm{~kg}$ of concentrate were fed daily. The ingredient (\% DM), proximate (\% DM), and fatty acid (\% total fatty acids) compositions of the concentrate fed to the dairy cows in experiment 2 are shown in Table 3. Water was available at all time for all the animals. Cows were milked twice daily (12-h milking interval). The morning milk was collected from animals individually after machine milking from the four quarters. The bulk tank somatic cell counts (SCC) were monitored and the values were less than 100,000 cells $/ \mathrm{ml}$. The milk samples were stored at $-20^{\circ} \mathrm{C}$ till milk fat analysis.

Table 2. Ingredients (kg, wet matter) and proximate (\% dry matter) composition of the TMR fed to dairy cows (Experiment 1)

\begin{tabular}{|c|c|}
\hline \multicolumn{2}{|l|}{ Ingredients } \\
\hline Grass haylage & 8.0 \\
\hline Corn silage & 10.0 \\
\hline Alfalfa hay & 3.8 \\
\hline Organic cows $1 \mathrm{a}^{1}$ & 7.5 \\
\hline Organic cows $1 b^{1}$ & 3.5 \\
\hline Organic cows $6^{1}$ & 5.0 \\
\hline Salt & 0.05 \\
\hline $\mathrm{Na}_{2} \mathrm{CO}_{3}$ & 0.15 \\
\hline Mineral/vitamin premix ${ }^{2}$ & 0.55 \\
\hline Total (wet matter) & 38.75 \\
\hline Dry matter intake (kg) & 24.2 \\
\hline \multicolumn{2}{|l|}{ Proximate composition } \\
\hline Total digestible nutrients (TDN) & 71 \\
\hline Crude protein & 18.5 \\
\hline Crude fat & 3.5 \\
\hline Acid detergent fiber (ADF) & 9.8 \\
\hline Neutral detergent fiber (NDF) & 18.8 \\
\hline Ashes & 3.9 \\
\hline Calcium & 0.9 \\
\hline Phosphorus & 0.4 \\
\hline \multicolumn{2}{|c|}{$\begin{array}{l}{ }^{1} \text { The details of these three ingredients are not shown here. } \\
{ }^{2} \text { Nutrients provided/kg of additive (Grobic-DC, Bayer Health Care, } \\
\text { Leverkusen, Germany): Vitamin A, 2,650,000 IU; Vitamin } \mathrm{D}_{3}, 530,000 \\
\text { IU; Vitamin E, } 1,050 \mathrm{IU} \text {; Niacin, } 10,000 \mathrm{mg} \text {; Mn, } 4,400 \mathrm{mg} \text {; Zn, } 4,400 \\
\mathrm{mg} \text {; Fe, } 13,200 \mathrm{mg} \text {; Cu, 2,200 mg; I, } 440 \mathrm{mg} \text {; Co, } 440 \mathrm{mg} \text {. }\end{array}$} \\
\hline
\end{tabular}

Table 3. Ingredients ( $\%$ dry matter), proximate ( $\%$ dry matter) and fatty acid (\% total fatty acids) composition of the concentrate ${ }^{1}$ fed to dairy cows (Experiment 2)

\begin{tabular}{|c|c|}
\hline \multicolumn{2}{|l|}{ Ingredients } \\
\hline Ground corn & 5.92 \\
\hline Wheat & 30.00 \\
\hline Salt & 0.82 \\
\hline Molasses & 3.75 \\
\hline Magnesium oxide & 0.50 \\
\hline Corn gluten meal & 10.82 \\
\hline Sodium bicarbonate & 0.70 \\
\hline Extruded soybean & 5.00 \\
\hline Palm kernel meal & 2.22 \\
\hline Urea & 1.00 \\
\hline Rapeseed meal & 4.56 \\
\hline Dried distilled grain solubles & 2.61 \\
\hline Soyhull & 6.54 \\
\hline Corn gluten feed & 18.51 \\
\hline Limestone & 1.70 \\
\hline Extruded linseed & 5.00 \\
\hline Mineral/vitamin premix ${ }^{2}$ & 0.35 \\
\hline Total & 100.00 \\
\hline \multicolumn{2}{|l|}{ Proximate composition } \\
\hline Ashes & $7.0 \pm 0.02$ \\
\hline Crude fat & $5.2 \pm 0.02$ \\
\hline Crude protein & $23.6 \pm 0.04$ \\
\hline Neutral detergent fiber (NDF) & 19.3 \\
\hline Acid detergent fiber (ADF) & 8.9 \\
\hline Calcium & $0.7 \pm 0.00$ \\
\hline Phosphorus & $0.4 \pm 0.00$ \\
\hline \multicolumn{2}{|l|}{ Fatty acid composition } \\
\hline C16:0 & $14.1 \pm 0.09$ \\
\hline $\mathrm{C} 18: 0$ & $4.6 \pm 0.01$ \\
\hline Oleic acid (C18:1n9c) & $20.6 \pm 0.03$ \\
\hline Linoleic acid (C18:2n6c) & $39.0 \pm 0.15$ \\
\hline Linolenic acid (C18:3n3) & $16.8 \pm 0.09$ \\
\hline \multicolumn{2}{|c|}{$\begin{array}{l}{ }^{1} \text { The ratio of roughage to concentrates is about } 0.77: 1 \text { (10 kg of oat hay } \\
\text { and } 13 \mathrm{~kg} \text { of concentrate were fed daily). } \\
{ }^{2} \text { Nutrients provided/kg of additive (Grobic-DC, Bayer Health Care, } \\
\text { Leverkusen, Germany): Vitamin A, 2,650,000 IU; Vitamin } \mathrm{D}_{3}, 530,000 \\
\mathrm{IU} \text {; Vitamin E, } 1,050 \mathrm{IU} \text {; Niacin, } 10,000 \mathrm{mg} \text {; Mn, } 4,400 \mathrm{mg} \text {; Zn, 4,400 } \\
\mathrm{mg} ; \mathrm{Fe}, 13,200 \mathrm{mg} ; \mathrm{Cu}, 2,200 \mathrm{mg} ; \mathrm{I}, 440 \mathrm{mg} \text {; Co, } 440 \mathrm{mg} \text {. }\end{array}$} \\
\hline
\end{tabular}

\section{Lipid analysis}

Briefly, total milk lipids were extracted with $20 \mathrm{ml}$ chloroform/methanol $(2: 1, \mathrm{v} / \mathrm{v})$ from $6 \mathrm{ml}$ of milk. The extracted lipids were then converted into fatty acid methyl esters with $14 \%(\mathrm{w} / \mathrm{v})$ boron trifluoride-methanol (B1252; Sigma-Aldrich Corp., St. Louis, MO, USA) according to a previously published method (Folch et al., 1957). The fatty acid methyl esters were then injected into a gas chromatograph (GC) (Agilent 7890A GC system, Agilent Technologies, USA) using a system equipped with a 7863 series auto-sampler, 7683B series injector, and flame ionization detector (FID). A $\mathrm{SP}^{\mathrm{TM}}-2560$ fused silica 
capillary column $(100 \mathrm{~m} \times 0.25 \mathrm{~mm}$, inner diameter with 0.2 $\mu \mathrm{m}$ film thickness; Supelco Inc., Bellefonte, PA, USA) was used and the oven temperature was programmed to increase from 70 to $225^{\circ} \mathrm{C}$ at a rate of $5^{\circ} \mathrm{C}$ per min to $100^{\circ} \mathrm{C}$, held for $2 \mathrm{~min}$, increased $10^{\circ} \mathrm{C}$ per min to $175^{\circ} \mathrm{C}$, held for 40 min, increased $5^{\circ} \mathrm{C}$ per min to $225^{\circ} \mathrm{C}$, and held for $40 \mathrm{~min}$. Front inlet and FID temperatures were maintained at $255^{\circ} \mathrm{C}$ and $260^{\circ} \mathrm{C}$, respectively. The hydrogen flow rate to the detector was $55 \mathrm{ml} / \mathrm{min}$, the airflow rate was $400 \mathrm{ml} / \mathrm{min}$, and the make-up gas flow rate was $20 \mathrm{ml} / \mathrm{min}$. The split ratio was $30: 1$. Peaks were routinely identified by comparing the retention time with those of authentic standards including Supelco ${ }^{\circledR} 37$ Component Fatty acid methyl esters (FAME) Mix (47885-U), trans-11octadecenoic methyl ester (46905-U; Sigma-Aldrich Corp.) and cis-9, trans-11 CLA (1255; Matreya LLC, Pleasant Gap, PA, USA). The percentage of individual fatty acid was calculated as the ratio of individual area to that of total identified fatty acids.

\section{Statistical analysis}

Data were presented as mean $\pm \mathrm{SE}$ and analyzed using a one-way analysis of variance (one-way ANOVA) (SPSS Inc., Chicago, USA). In all cases, significant differences were accepted if $\mathrm{p}<0.05$. The relationship between cis-9, trans-11 CLA content and desaturation indexes were analyzed using the correlation procedures (PROC CORR) of SAS (SAS, 2000).

\section{RESULTS AND DISCUSSION}

\section{Effects of lactation stage on milk cis-9, trans-11 CLA content}

Previous studies have shown that lactation stage significantly contributes to variation in the milk fat profile (Kay et al., 2005; Stoop et al., 2009). Normally, linoleic acid can be isomerized into cis-9, trans-11 CLA in the rumen, with the majority being further hydrogenated into trans-11 18:1, and then potentially saturated into stearic acid (Wang and Lee, 2012). In experiment 1, both the linoleic acid and stearic acid levels significantly decreased from the early stage of lactation (before $100 \mathrm{~d}$ ) to the late stage (after $200 \mathrm{~d})(\mathrm{p}=0.032$ and $\mathrm{p}=0.022$, respectively; Table 4). Because the animals were offered the same diet, the decreased linoleic acid and stearic acid levels in milk may suggest increased activity of rumen microorganisms and more rumen output of trans-11 $18: 1$ by dairy cows in the late stage of lactation.

The milk trans-C18:1 content of dairy cows in middle stage of lactation was significantly lower than that in early stage of lactation $(\mathrm{p}=0.003)$ whereas no significant difference was found between the late stage and early stage $(p=0.087)$ (Table 4). Three desaturation indexes were calculated representing the ratio of the $\Delta 9$-desaturase product to the sum of the $\Delta 9$-desaturase product and substrate (Kelsey et al., 2003) (Table 4). Although not statistically significant, the desaturation indexes for cis-9 C14:1 and cis-9 C18:1 in the late stage of lactation were all

Table 4. Differences in major milk fatty acids (\%) from dairy cows in Experiment 1

\begin{tabular}{|c|c|c|c|c|c|c|}
\hline \multirow{2}{*}{$\frac{\text { Items }}{\text { Fatty acid (\%) }}$} & \multicolumn{2}{|c|}{ Early stage } & \multicolumn{2}{|c|}{ Middle stage } & \multicolumn{2}{|c|}{ Late stage } \\
\hline & Mean \pm SE & Range & Mean \pm SE & Range & Mean \pm SE & Range \\
\hline$\overline{\mathrm{C} 12: 0 \text { (Lauric acid) }}$ & $1.88 \pm 0.258^{\mathrm{a} 1}$ & $0.71-3.45$ & $2.75 \pm 0.092^{\mathrm{b}}$ & $2.23-3.30$ & $2.67 \pm 0.144^{\mathrm{ab}}$ & $2.07-2.99$ \\
\hline C14:0 (Myristic acid) & $9.17 \pm 0.813^{\mathrm{a}}$ & $5.26-13.69$ & $12.38 \pm 0.194^{\mathrm{b}}$ & $11.2-13.41$ & $12.04 \pm 0.417^{\mathrm{b}}$ & $10.05-13.92$ \\
\hline C14:1 (Myristoleic acid) & $0.56 \pm 0.073^{\mathrm{a}}$ & $0.29-1.08$ & $0.89 \pm 0.044^{\mathrm{b}}$ & $0.63-1.06$ & $0.85 \pm 0.060^{\mathrm{b}}$ & $0.64-1.21$ \\
\hline C16:0 (Palmitic acid) & $27.66 \pm 0.536^{\mathrm{a}}$ & $25.25-30.53$ & $30.20 \pm 0.503^{b}$ & $27.16-32.63$ & $29.78 \pm 1.000^{\mathrm{b}}$ & 26.61-35.29 \\
\hline C16:1 (Palmitoleic acid) & $1.47 \pm 0.177^{\mathrm{b}}$ & $0.92-2.66$ & $1.11 \pm 0.071^{\mathrm{a}}$ & $0.92-1.77$ & $1.13 \pm 0.068^{\mathrm{ab}}$ & $0.79-1.45$ \\
\hline C18:0 (Stearic acid) & $17.70 \pm 0.719^{\mathrm{b}}$ & $13.92-22.40$ & $15.17 \pm 0.444^{\mathrm{a}}$ & $12.91-17.71$ & $15.00 \pm 1.076^{\mathrm{a}}$ & $10.58-20.31$ \\
\hline trans-11 C18:1 & $1.47 \pm 0.050^{\mathrm{b}}$ & $1.23-1.75$ & $1.26 \pm 0.036^{\mathrm{a}}$ & $1.09-1.49$ & $1.35 \pm 0.047^{\mathrm{ab}}$ & $1.04-1.59$ \\
\hline C18:1n9c (Oleic acid) & $27.32 \pm 1.464^{\mathrm{b}}$ & $20.47-35.20$ & $22.69 \pm 0.571^{\mathrm{a}}$ & $19.01-25.31$ & $23.75 \pm 0.863^{\mathrm{a}}$ & $19.68-27.83$ \\
\hline C18:2n6c (Linoleic acid) & $3.20 \pm 0.112^{\mathrm{b}}$ & $2.81-3.98$ & $2.99 \pm 0.079^{\mathrm{ab}}$ & $2.61-3.66$ & $2.88 \pm 0.091^{\mathrm{a}}$ & $2.48-3.25$ \\
\hline C18:3n3 (Linolenic acid) & $0.35 \pm 0.016$ & $0.28-0.48$ & $0.36 \pm 0.008$ & $0.32-0.43$ & $0.36 \pm 0.014$ & $0.29-0.40$ \\
\hline cis-9, trans-11 CLA & $0.33 \pm 0.043^{\mathrm{a}}$ & $0.27-0.38$ & $0.37 \pm 0.010^{\mathrm{a}}$ & $0.30-0.42$ & $0.44 \pm 0.021^{\mathrm{b}}$ & $0.36-0.57$ \\
\hline Other & $8.88 \pm 0.500$ & $6.19-11.56$ & $9.83 \pm 0.172$ & $8.67-10.68$ & $9.75 \pm 0.188$ & $8.80-10.40$ \\
\hline \multicolumn{7}{|l|}{ Desaturation index ${ }^{2}$} \\
\hline cis $14: 1$ & $0.06 \pm 0.004$ & $0.03-0.08$ & $0.07 \pm 0.003$ & $0.05-0.08$ & $0.07 \pm 0.004$ & $0.06-0.09$ \\
\hline cis $16: 1$ & $0.04 \pm 0.003$ & $0.03-0.05$ & $0.04 \pm 0.002$ & $0.03-0.05$ & $0.04 \pm 0.001$ & $0.03-0.04$ \\
\hline cis $18: 1$ & $0.60 \pm 0.015$ & $0.54-0.70$ & $0.60 \pm 0.010$ & $0.54-0.63$ & $0.62 \pm 0.015$ & $0.54-0.69$ \\
\hline
\end{tabular}

\footnotetext{
$1, \mathrm{a}-\mathrm{c}$ within a row, values with different superscripts is significantly different $(\mathrm{p}<0.05)$.

${ }^{2}$ Desaturation index are calculated as following: ratio of the $\Delta 9$-desaturase product divided by the sum of the $\Delta 9$-desaturase product and substrate. For example, the desaturase index for cis-9 14:1 would be (cis-9 14:1)/(cis-9 14:1+14:0).
} 


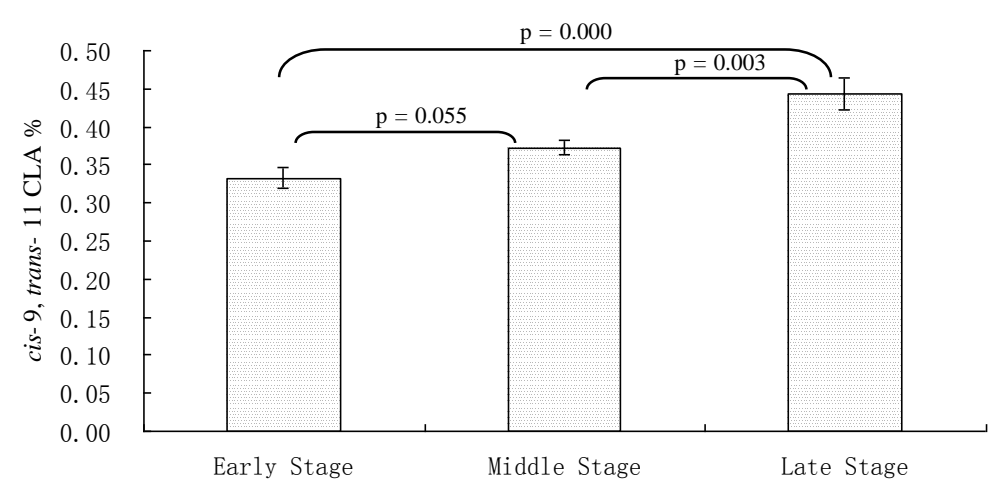

Figure 1. cis-9, trans-11 CLA content in milk from dairy cows at different lactation stages (Experiment 1).

a little higher than that in the early stage of lactation $(\mathrm{p}=$ 0.116 and $p=0.609$, respectively; Table 4 ) and these results may indirectly imply a higher activity of $\Delta 9$-desaturase of the mammary glands of animals in the late stage of lactation. However, no difference was found for the desaturation index for cis-9 C16:1. As we have speculated, the cis-9, trans-11 CLA continually increased from the early stage of lactation to the late stage of lactation $(0.33 \%$ vs $0.44 \%$; Figure 1). A similar result was also found in the milk of Canadian Jersey cows, with the cis-9, trans-11 CLA content in the late stage (after $200 \mathrm{~d}$ ) being significantly higher than during early lactation (before $100 \mathrm{~d}$ ) (Kgwatalala et al., 2009). In a dairy ewe research, greatly increased cis-9, trans-11 CLA content was observed in Transylvania Merino sheep (2.03 g vs $2.70 \mathrm{~g} / 100 \mathrm{~g}$ FAME), Tsigay sheep (2.05 g vs $2.60 \mathrm{~g} / 100 \mathrm{~g}$ FAME) and Turcana sheep (2.36 g vs 3.64 $\mathrm{g} / 100 \mathrm{~g}$ FAME) from 2 wks to 14 wks of lactation (Mierlita et al., 2011). However, in another report it was said that the cis-9, trans-11 CLA content of bovine milk and $\Delta 9$ desaturase activity in the mammary gland are independent of stage of lactation under normal conditions (Lock et al., 2005).

Effects of individual performance on milk cis-9, trans-11 CLA content

The individual contents of the major fatty acids, especially cis-9, trans-11 CLA in cows of the same lactation were found variable in experiment 1 . In milk, cis-9, trans11 CLA contents were 0.27 to $0.38 \%, 0.30$ to $0.42 \%$, and 0.36 to $0.57 \%$ in the early stage, middle stage and later stage, respectively (Table 4). These data suggested large individual differences in the cis-9, trans-11 CLA synthesis ability of cows offered the same diet and this may be related to both rumen biohydrogenation and $\Delta 9$-desaturase activity in the mammary gland (Lock and Garnsworthy, 2002; Peterson et al., 2002).

In order to confirm if individual performance really had effect on milk cis-9, trans-11 CLA content, experiment 2 was designed as a validation test. More animals in middle lactation were used in this experiment (17 multiparous Holstein cows) compared with that in experiment 1 (11 multiparous Holstein cows). Our results once again showed that the individual contents of cis-9, trans-11 CLA were various, and a difference of about 2 -fold $(0.55 \%$ vs $0.95 \%)$ was observed although the animals were offered same diet (Figure 2). Corresponding differences were also evident in the desaturation indexes for cis-9 $\mathrm{C} 14: 1$ (0.069 vs 0.137) and cis-9 C16:1 (0.036 vs 0.064) (Table 5). These substantial variations in the desaturation indexes may demonstrate a huge diversity of the $\Delta 9$-desaturase activity in mammary glands of dairy cows. A positive correlation $\left(\mathrm{R}^{2}=0.558\right)$ existed between cis-9, trans-11 CLA content

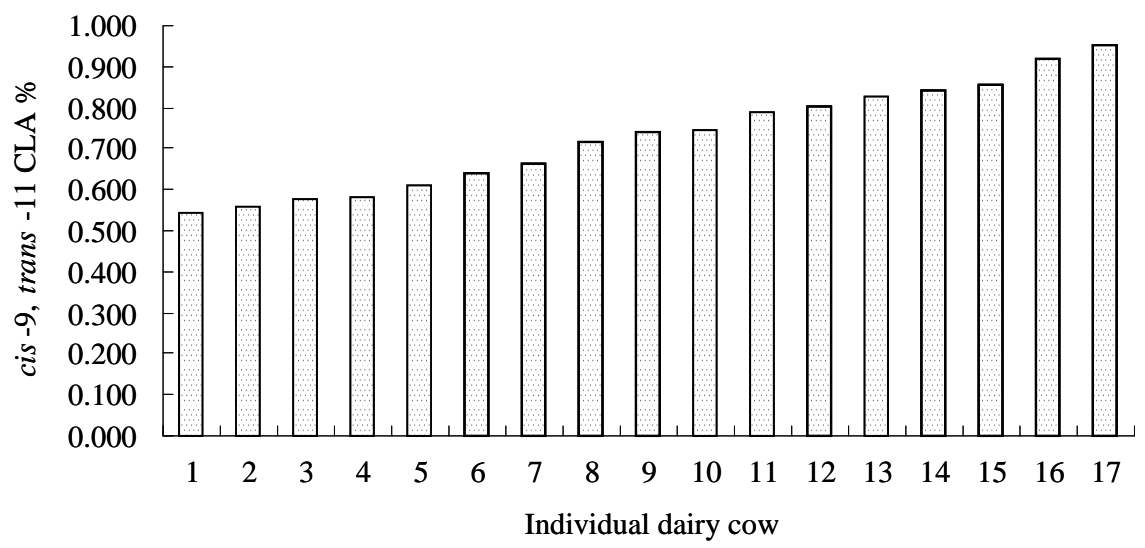

Figure 2. cis-9, trans-11 CLA content of milk from individual multiparous dairy cows in the middle lactation stage (Experiment 2). 
Table 5. Important parameters and major milk fatty acids composition (\%) from dairy cows in Experiment 2

\begin{tabular}{|c|c|c|}
\hline Items & Mean \pm SE & Range \\
\hline Milk yield (L) & $19.89 \pm 2.32$ & $17-24$ \\
\hline Milk protein $(\%)$ & $3.28 \pm 0.32$ & $2.93-4.22$ \\
\hline Milk lactose (\%) & $5.01 \pm 0.11$ & $4.83-5.15$ \\
\hline Fat content $(\%)$ & $3.55 \pm 0.85$ & $2.37-5.21$ \\
\hline \multicolumn{3}{|l|}{ Fatty acid composition (\%) } \\
\hline C12:0 (Lauric acid) & $2.87 \pm 0.197$ & $1.57-4.46$ \\
\hline C14:0 (Myristic acid) & $10.34 \pm 0.283$ & $7.9-11.60$ \\
\hline C14:1 (Myristoleic acid) & $1.08 \pm 0.073$ & $0.64-1.60$ \\
\hline C16:0 (Palmitic acid) & $28.01 \pm 0.488$ & $24.81-31.16$ \\
\hline C16:1(Palmitoleic acid) & $1.40 \pm 0.051$ & $1.06-1.76$ \\
\hline C18:0 (Stearic acid) & $11.97 \pm 0.471$ & $9.05-15.66$ \\
\hline trans-11 C18:1 & $2.09 \pm 0.082$ & $1.76-2.92$ \\
\hline C18:1n9c (Oleic acid) & $26.39 \pm 0.617$ & $22.37-31.10$ \\
\hline C18:2n6c (Linoleic acid) & $3.79 \pm 0.172$ & $2.47-5.32$ \\
\hline C18:3n3 (Linolenic acid) & $0.46 \pm 0.027$ & $0.34-0.68$ \\
\hline cis-9, trans-11 CLA & $0.73 \pm 0.031$ & $0.55-0.95$ \\
\hline Other & $10.88 \pm 0.461$ & $8.22-14.25$ \\
\hline \multicolumn{3}{|l|}{ Desaturation index $^{1}$} \\
\hline cis $14: 1$ & $0.09 \pm 0.005$ & $0.069-0.137$ \\
\hline cis $16: 1$ & $0.05 \pm 0.002$ & $0.036-0.064$ \\
\hline cis $18: 1$ & $0.69 \pm 0.009$ & $0.601-0.735$ \\
\hline $\begin{array}{l}1 \text { Desaturation index are cal } \\
\text { desaturase product divided by } \\
\text { substrate. For example, the des } \\
914: 1) /(\text { cis }-914: 1+14: 0) \text {. }\end{array}$ & as following & $\begin{array}{l}\text { atio of the } \Delta 9- \\
\text { rase product and } \\
: 1 \text { would be ( } \mathrm{cis}-\end{array}$ \\
\hline
\end{tabular}

and the desaturation index for cis-9 C14:1 (Figure 3). However, no obvious correlation was found between cis-9, trans-11 CLA content and the desaturation index for cis-9 C16:1 $\left(\mathrm{R}^{2}=0.087\right)$ or cis-9 C18:1 $\left(\mathrm{R}^{2}=0.218\right)$ (Figure 3). Moreover, large variations were found in the milk content of linoleic acid $(2.47 \%$ to $5.32 \%)$ and linolenic acid $(0.34 \%$ to $0.68 \%$ ) further suggesting considerable differences in the rumen environments of these animals. In addition, various individual cis-9, trans-11 CLA contents were also found in two crossbreed dairy ewes including Karakachan $\times$ Blackhead Pleven (13.5 to $28.8 \mathrm{mg} / \mathrm{g}$ fat) and Tsigayx Blackhead Pleven (13.7 to $43.6 \mathrm{mg} / \mathrm{g}$ fat) (Mihailova and Odjakova, 2011). Lastly, two additional aspects were again confirmed from the results of these 2 experiments (Table 4; Figure 3). First, higher desaturation indexes correspond to higher cis-9, trans-11 CLA content and second, the desaturation index of cis-9 C14:1 appears to be a much more reliable indicator than that of cis-9 C16:1 or cis-9 C18:1.

In conclusion, our results demonstrated that lactation stage and individual performance have considerable effects on the milk fat profile in dairy cows, especially in the content of cis-9, trans-11 CLA. Furthermore, the basis for the variation of cis-9, trans-11 CLA content at the
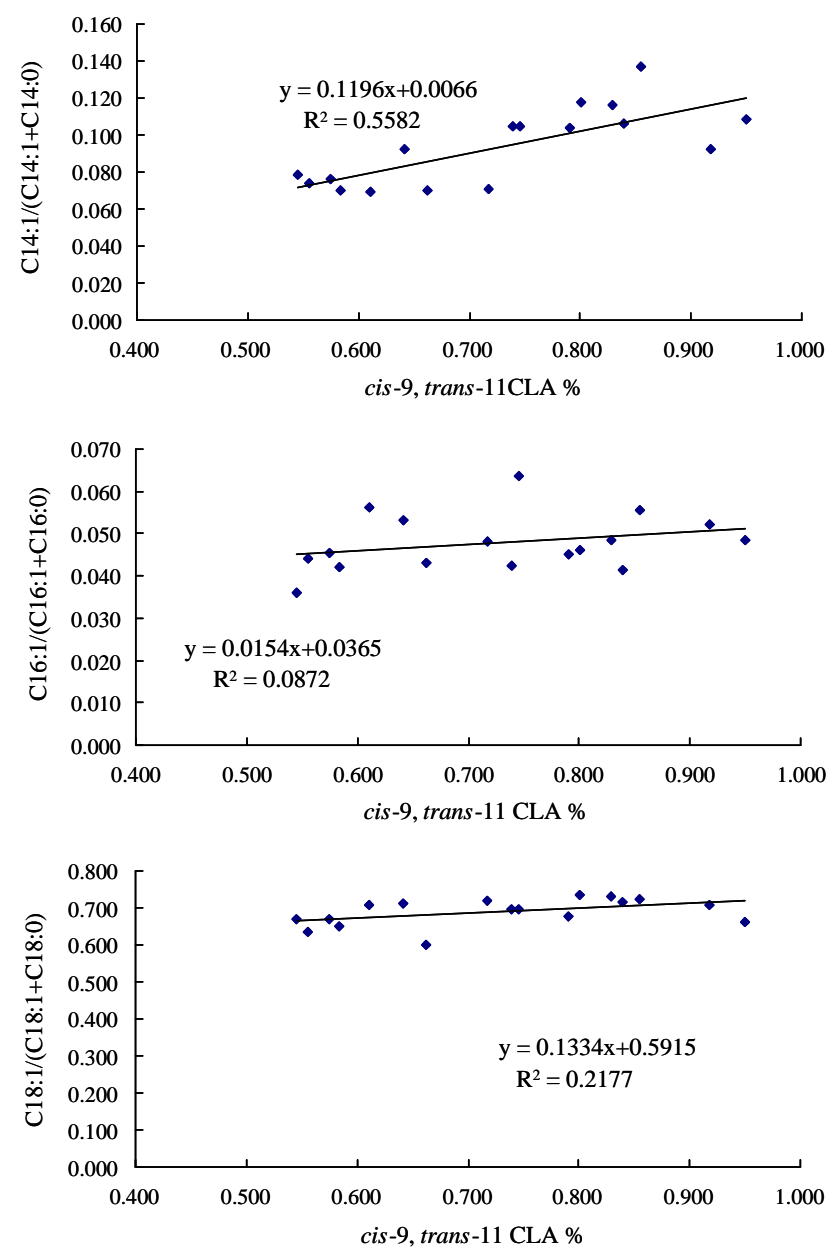

Figure 3. Correlation between cis-9, trans-11 CLA content and desaturation indexes (Experiment 2).

individual level and during lactation may be related to the rumen output of trans-11 $18: 1$ and to the activity of $\Delta 9$ desaturase in the mammary glands.

\section{ACKNOWLEDGEMENTS}

This research was supported by Basic Science Research Program through the National Research Foundation of Korea (NRF) funded by the Ministry of Education, Science and Technology (Project No. 010-0006707).

\section{REFERENCES}

Bauman, D. E., L. H. Baumgard, B. A. Corl and J. M. Griinari. 2000. Biosynthesis of conjugated linoleic acid in ruminants. J. Anim. Sci. 77(E-Suppl):1-15.

Dhiman, T. R., S. H. Nam and A. L. Ure. 2005. Factors affecting conjugated linoleic acid content in milk and meat. Crit. Rev. Food. Sci. Nutr. 45:463-482.

Folch, J., M. Lees and G. H. S. Stanley. 1957. A simple method for the isolation and purification of total lipids from animal tissues. J. Biol. Chem. 226:497-509.

Griinari, J. M., B. A. Corl, S. H. Lacy, P. Y. Chouinard, K. V. 
Nurmela and D. E. Bauman. 2000. Conjugated linoleic acid is synthesized endogenously in lactating dairy cows by $\Delta 9$ desaturase. J. Nutr. 130:2285-2291.

Jacobs, A. A. A. 2011. Nutritional regulation of stearoyl-CoA desaturase in the bovine mammary gland. Ph.D. Thesis, Wageningen University, Wageningen, Netherlands.

Kay, J. K., W. J. Weber, C. E. Moore, D. E. Bauman, L. B. Hansen, H. Chester-Jones, B. A. Crooker and L. H. Baumgard. 2005. Effects of week of lactation and genetic selection for milk yield on milk fatty acid composition in Holstein cows. J. Dairy Sci. 88:3886-3893.

Kelsey, J. A., B. A. Corl, R. J. Collier and D. E. Bauman. 2003. The effect of breed, parity, and stage of lactation on conjugated linoleic acid (CLA) in milk fat from dairy cows. J. Dairy Sci. 86:2588-2597.

Kgwatalala, P. M., E. M. Ibeagha-Awemu, A. F. Mustafa and X. Zhao. 2009. Influence of stearoyl-coenzyme A desaturase 1 genotype and stage of lactation on fatty acid composition of Canadian Jersey cows. J. Dairy Sci. 92:1220-1228.

Lengi, A. J. and B. A. Corl. 2007. Identification and characterization of a novel bovine stearoyl-CoA desaturase isoform with homology to human SCD5. Lipids 42:499-508.

Lock, A. L., D. E. Bauman and P. C. Garnsworthy. 2005. Short communication: Effect of production variables on the cis-9, trans-11 conjugated linoleic acid content of cows' milk. J. Dairy Sci. 88:2714-2717.

Lock, A. L. and P. C. Garnsworthy. 2002. Independent effects of dietary linoleic and linolenic fatty acids on the conjugated linoleic acid content of cows' milk. Anim. Sci. 74:163-176.
Mierlita, D., E. Hilma, S. Daraban and F. Lup. 2011. Influence of lactation stage on milk yield and milk fatty acid profile in dairy ewes. Bull. UASVM Anim. Sci. Biol. 68:217-224.

Mihailova, G. and T. Odjakova. 2011. CLA content in sheep milk and sheep dairy products. Maced. J. Anim. Sci. 1:195-200.

Paton, C. M. and J. M. Ntambi. 2009. Biochemical and physiological function of stearoyl-CoA desaturase. Am. J. Physiol. Endocrinol. Metab. 297:E28-E37.

Peterson, D. G., J. A. Kelsey and D. E. Bauman. 2002. Analysis of variation in cis-9, trans-11 conjugated linoleic acid (CLA) in milk fat of dairy cows. J. Dairy Sci. 85:2164-2172.

Rodríguez-Alcalá L. M. and J. Fontecha. 2007. Hot topic: Fatty acid and conjugated linoleic acid (CLA) isomer composition of commercial CLA-fortified dairy products: evaluation after processing and storage. J. Dairy Sci. 90:2083-2090.

SAS. 2000. SAS user's guide: Statistics (Version 8.01 Ed). SAS Inst. Inc., Cary, NC, USA.

Slots, T., G. Butler, C. Leifert, T. Kristensen, L. H. Skibsted and J. H. Nielsen. 2008. Potentials to differentiate milk composition by different feeding strategies. J. Dairy Sci. 92:2057-2066.

Stoop, W. M., H. Bovenhuis, J. M. L. Heck and J. A. M. van Arendonk. 2009. Effect of lactation stage and energy status on milk fat composition of Holstein-Friesian cows. J. Dairy Sci. 92:1469-1478.

Wang, T. and H. G. Lee. 2012. Advances in research on cis-9, trans-11 conjugated linoleic acid: A major functional conjugated linoleic acid isomer. Crit. Rev. Food Sci. Nutr. (In press) (ID: 674071 DOI:10.1080/10408398.2012.674071). 